\title{
A compact VEGF signature associated with distant metastases and poor outcomes \\ Zhiyuan $\mathrm{Hu}^{1,2}$, Cheng Fan1 ${ }^{1}$, Chad Livasy ${ }^{1,3}$, Xiaping $\mathrm{He}^{1,2}$, Daniel S Oh${ }^{1,2}$, Matthew G Ewend ${ }^{1,4}$, Lisa A Carey ${ }^{1,4}$, Subbaya Subramanian ${ }^{5}$, Robert West ${ }^{5}$, Francis Ikpatt ${ }^{6}$, Olufunmilayo I Olopade ${ }^{6}$, Matt van de Rijn ${ }^{5}$ and Charles M Perou*1,2,3
}

\begin{abstract}
Address: ${ }^{1}$ Lineberger Comprehensive Cancer Center, University of North Carolina at Chapel Hill, Chapel Hill, NC 27599, USA, ${ }^{2}$ Department of Genetics, University of North Carolina at Chapel Hill, Chapel Hill, NC 27599, USA, ${ }^{3}$ Department of Pathology and Laboratory Medicine, University of North Carolina at Chapel Hill, Chapel Hill, NC 27599, USA, ${ }^{4}$ Department of Medicine, University of North Carolina at Chapel Hill, Chapel Hill, NC 27599, USA, ${ }^{5}$ Department of Pathology, Stanford University Medical Center, Stanford, CA 94035, USA and ${ }^{6}$ Section of Hematology/Oncology, Department of Medicine, Committees on Genetics and Cancer Biology, University of Chicago, South Maryland Avenue, Chicago, IL 60637-1463, USA

Email: Zhiyuan Hu - zhiyuan_hu@med.unc.edu; Cheng Fan - cfan2004@gmail.com; Chad Livasy - chad_livasy@med.unc.edu; Xiaping He - xiaping_he@med.unc.edu; Daniel S Oh - daniel_oh@med.unc.edu; Matthew G Ewend - ewend@med.unc.edu; Lisa A Carey - Lisa_Carey@med.unc.edu; Subbaya Subramanian - subbaya_subramanian@stanford.edu; Robert West - rbwest@stanford.edu; Francis Ikpatt - fikpatt@medicine.bsd.uchicago.edu; Olufunmilayo I Olopade - folopade@medicine.bsd.uchicago.edu; Matt van de Rijn - mrijn@stanford.edu; Charles M Perou* - cperou@med.unc.edu

* Corresponding author
\end{abstract}

Published: 16 March 2009

BMC Medicine 2009, 7:9 doi:10.1/86/1741-7015-7-9
Received: 23 February 2009

Accepted: 16 March 2009

This article is available from: http://www.biomedcentral.com/I74I-70I5/7/9

(C) 2009 Hu et al; licensee BioMed Central Ltd.

This is an Open Access article distributed under the terms of the Creative Commons Attribution License (http://creativecommons.org/licenses/by/2.0), which permits unrestricted use, distribution, and reproduction in any medium, provided the original work is properly cited.

\begin{abstract}
Background: Tumor metastases pose the greatest threat to a patient's survival, and thus, understanding the biology of disseminated cancer cells is critical for developing effective therapies.
\end{abstract}

Methods: Microarrays and immunohistochemistry were used to analyze primary breast tumors, regional (lymph node) metastases, and distant metastases in order to identify biological features associated with distant metastases.

Results: When compared with each other, primary tumors and regional metastases showed statistically indistinguishable gene expression patterns. Supervised analyses comparing patients with distant metastases versus primary tumors or regional metastases showed that the distant metastases were distinct and distinguished by the lack of expression of fibroblast/mesenchymal genes, and by the high expression of a 13-gene profile (that is, the 'vascular endothelial growth factor (VEGF) profile') that included VEGF, ANGPTL4, ADM and the monocarboxylic acid transporter SLCI6A3. At least 8 out of 13 of these genes contained HIFI $\alpha$ binding sites, many are known to be HIFI $\alpha$-regulated, and expression of the VEGF profile correlated with HIFI $\alpha$ IHC positivity. The VEGF profile also showed prognostic significance on tests of sets of patients with breast and lung cancer and glioblastomas, and was an independent predictor of outcomes in primary breast cancers when tested in models that contained other prognostic gene expression profiles and clinical variables.

Conclusion: These data identify a compact in vivo hypoxia signature that tends to be present in distant metastasis samples, and which portends a poor outcome in multiple tumor types.

This signature suggests that the response to hypoxia includes the ability to promote new blood and lymphatic vessel formation, and that the dual targeting of multiple cell types and pathways will be needed to prevent metastatic spread. 


\section{Background}

Metastases are the main cause of mortality for patients with breast cancer. The molecular biology behind metastasis is complex and likely requires changes in cell cycle regulation [1], the repertoire of expressed proteases and protease inhibitors [2], proteins that promote autocrine growth loops, and/or proteins that cause an epithelial-tomesenchymal transition [3]. To make matters more complicated, it is clear that metastasis biology is in part governed by non-tumor cells including fibroblasts [4], endothelial cells [5], and myoepithelial cells [6]. For example, recent evidence suggests that tumor endothelial cell interactions are important for determining patient outcomes as evidenced by the promising results from clinical trials that use bevacizumab, a monoclonal antibody directed against vascular endothelial growth factor (VEGF) [7,8].

Genomic profiling of human tumors and model systems has identified important features concerning metastasis biology. First, it has been shown that the expression profile of primary tumors without metastases can be highly predictive of the development of future metastases [9-13]. Second, cell lines can be selected that have specific endorgan tropisms with distinct expression profiles $[14,15]$. Finally, cell line and murine models have demonstrated many different genes as being important for breast tumor metastasis, including Twist [16], Snail [3], and CXCL12 [17]. In this paper, we compare primary breast tumors, regional metastases, and distant metastases with each other and show that distant metastasis samples are distinct and provide unique signatures that predict poor outcomes in primary tumors.

\section{Methods}

\section{Tissue samples and microarray protocols}

One hundred and forty-six patients represented by 161 breast tumor specimens (with 23 paired tumor samples) and 10 normal breast samples (195 total microarrays) were profiled. Most of these samples appeared in previous publications [18-20], with 39 being new to this study, and all of which were collected using institutional review board-approved protocols. The clinical information for all samples is in the table in Additional file 1. Included within the 161 profiled tumors were 134 primary tumors, nine regional metastases and 18 distant metastases. Patients were heterogeneously treated in accordance with the standard of care dictated by their disease stage, estrogen receptor (ER) and HER2 status.

Total RNA isolation and microarray protocols are described in Hu et al [21]. Each sample was assayed versus a common reference sample [22]. The microarrays used were Agilent Human oligonucleotide microarrays that were scanned on an Axon GenePix 4000B, analyzed with
GenePix Pro 4.1, and Lowess normalized. All microarray data have been deposited into the GEO under the accession number of GSE3521.

\section{Supervised microarray data analysis}

The background-subtracted, Lowess-normalized $\log _{2}$ ratio of Cy5 over Cy3 intensity values were filtered to select genes that had a signal intensity of $>30$ units in both the $\mathrm{Cy} 5$ and $\mathrm{Cy} 3$ channels. Only genes that met these criteria in at least $70 \%$ of the 195 microarrays were included for subsequent analysis. Next, each patient was classified according to the following metastasis scoring system (MetScore): MetScore $=1$ were patients that had a primary tumor and were clinically node negative $(N=0)$ and distant metastasis negative $(M=0)$; MetScore $=2$ were patients that had a regional metastasis $(N=1-3)$ and no distant metastasis $(M=0)$; MetScore $=3$ were patients with confirmed distant disease at the time of diagnosis $(M$ $=1$ and any $N$ ) or that were represented by an actual distant metastasis sample. We next performed a multi-class significance analysis of microarrays (SAM) using a single sample from each patient, biasing the sample selection to use the actual regional or distant metastasis samples (146 arrays, see Additional file 1). We identified the gene set that was associated with the MetScore 1-2-3 distinction, which gave 1195 genes at a false discovery rate of $5 \%$. This gene set was next used in a one-way average linkage hierarchical cluster using the program 'Cluster' [23], with the data being displayed relative to the median expression for each gene using 'Java Treeview' [24].

\section{Cross-validation analyses}

Relationships between the gene expression data and the MetScore classification was further examined using a 10fold cross-validation (CV) analysis to identify a set of genes that might distinguish a MetScore group from the others. 10-fold CV using five different statistical predictors including PAM [25], a $k$-nearest neighbor classifier with either Euclidean distance or one-minus-Spearman-correlation as the distance function, and a class nearest centroid metric with either Euclidean distance or one-minusSpearman-correlation as the distance function, were used as described in Chung et al [26]. We performed 10-fold $\mathrm{CV}$ using the five different statistical predictors with the reported $\mathrm{CV}$ prediction accuracies being the average of the five predictors (Tables 1, 2, 3 and 4).

\section{VEGF profile analyses}

For the VEGF profile, an average expression value across all 13 genes (RRAGD, FABP5, UCHL1, GAL, PLOD, DDIT4, VEGF, ADM, ANGPTL4, NDRG1, NP, SLC16A3 and C14ORF58) was determined and the patients were placed into a three-group classification based their 13gene average $\log _{2}$ expression ratio from the University of North Carolina (UNC) training data set and using the cut 
Table I: Cox proportional hazards models for relapse-free survival using the NKI 295 patient test data set - model containing the clinical variables and the VEGF profile

\begin{tabular}{|c|c|c|c|c|c|c|c|c|}
\hline \multirow{2}{*}{$\begin{array}{l}\text { Variable } \\
\text { Age }\end{array}$} & \multirow{2}{*}{$\begin{array}{l}\text { DF } \\
1\end{array}$} & \multirow{2}{*}{$\begin{array}{l}\text { Estimate } \\
-0.05508\end{array}$} & \multirow{2}{*}{$\begin{array}{l}\text { Standard Error } \\
0.01622 \\
\end{array}$} & \multirow{2}{*}{$\begin{array}{l}\text { Chi-Square } \\
11.5365\end{array}$} & \multirow{2}{*}{$\begin{array}{l}\text { Pr }>\text { ChiSq } \\
0.0007\end{array}$} & \multirow{2}{*}{$\begin{array}{l}\text { Hazard Ratio } \\
0.946\end{array}$} & \multicolumn{2}{|c|}{$\begin{array}{l}\text { 95\% Hazard Ratio Confidence } \\
\text { Limits }\end{array}$} \\
\hline & & & & & & & 0.917 & 0.977 \\
\hline$E R$ & 1 & -0.12785 & 0.23563 & 0.2944 & 0.5874 & 0.88 & 0.555 & 1.397 \\
\hline Grade2vsI & i & 0.8058 & 0.31181 & 6.6784 & 0.0098 & 2.238 & 1.215 & 4.124 \\
\hline Grade3vs I & I & 0.76706 & 0.32265 & 5.6519 & 0.0174 & 2.153 & $\mathrm{I} .144$ & 4.053 \\
\hline Tsize & 1 & 0.37409 & 0.19444 & 3.7017 & 0.0544 & $\mathrm{I} .454$ & 0.993 & 2.128 \\
\hline node & I & 0.33066 & 0.17801 & 3.4504 & 0.0632 & 1.392 & 0.982 & 1.973 \\
\hline Treatment & I & -0.65688 & 0.27811 & 5.5788 & 0.0182 & 0.518 & 0.301 & 0.894 \\
\hline VEGF_3group & I & 0.47238 & 0.14838 & 10.1355 & 0.0015 & 1.604 & 1.199 & 2.145 \\
\hline
\end{tabular}

off values $(-0.63 / 0.08)$ that were identified using X-tile [27] and relapse-free survival as the endpoint. Analyses using the VEGF profile and the training set cutoffs were also applied to an independent test set of 295 patients assayed on Agilent microarrays (that is, NKI295 [28]), to a set of lung carcinoma samples from Bhattacharjee et al [29], and to the glioblastoma sample set from Nutt et al [30]. To perform these across-data set analyses, for the NKI295 dataset we used the log ratio of red channel intensity versus green channel intensity and the data was median centered for every gene across the 295 arrays. The Netherlands Cancer Institute (NKI) dataset was then distant weight discrimination (DWD) normalized [31] with the UNC training dataset after collapsing by NCBI Entrez GeneID; after DWD normalization, the NKI data was also column standardized. For the Affymetrix datasets the probe level intensity .CEL files were processed by robust multi-chip average. The probe sets' log intensity was median centered for every gene across all the arrays. The
Affymetrix datasets were also DWD normalized relative to the UNC training data after collapsing by NCBI Entrez GeneID, and were column standardized.

\section{Multiple expression predictor analyses}

First, each sample was assigned an 'intrinsic subtype' as described in Hu et al [18], where a centroid was created for each of the following intrinsic subtypes: Basal-like, Luminal A, Luminal B, HER2-enriched and Normal-like. Next, we tested for associations between a tumor's intrinsic subtype, the VEGF profile and other published expression profiles implicated in metastasis biology that included a) the 70-gene outcome predictor developed by van't Veer et al $[10,11], \mathrm{b})$ the 'wound-response' profile $[32], \mathrm{c})$ the hypoxia-induced cell line signature [33], d) the 11-gene $\mathrm{BMI} /$ stem cell signature [34], e) a bone metastasis signature [14], f) a lung metastasis signature [15], and g) the expression profiles of $H I F 1 \alpha$, Snail [3] and Twist [16]; we extracted as many genes as was possible from our micro-

Table 2: Cox proportional hazards models for relapse-free survival using the NKI 295 patient test data set - model containing the clinical variables and multiple gene expression profiles

\begin{tabular}{|c|c|c|c|c|c|c|c|c|}
\hline \multirow{2}{*}{$\begin{array}{l}\text { Variable } \\
\text { Age }\end{array}$} & \multirow{2}{*}{$\begin{array}{l}\text { DF } \\
\text { I }\end{array}$} & \multirow{2}{*}{$\begin{array}{l}\text { Estimate } \\
-0.0505\end{array}$} & \multirow{2}{*}{$\begin{array}{l}\text { Standard Error } \\
0.0174\end{array}$} & \multirow{2}{*}{$\begin{array}{l}\text { Chi-Square } \\
8.4217\end{array}$} & \multirow{2}{*}{$\begin{array}{l}\text { Pr }>\text { ChiSq } \\
0.0037\end{array}$} & \multirow{2}{*}{$\begin{array}{l}\text { Hazard Ratio } \\
0.951\end{array}$} & \multicolumn{2}{|c|}{$\begin{array}{l}\text { 95\% Hazard Ratio Confidence } \\
\text { Limits }\end{array}$} \\
\hline & & & & & & & 0.919 & 0.984 \\
\hline ER & I & -0.5654 & 0.34723 & 2.6514 & 0.1035 & 0.568 & 0.288 & 1.122 \\
\hline Grade2vsI & I & 0.15563 & 0.33471 & 0.2162 & 0.642 & 1.168 & 0.606 & 2.252 \\
\hline Grade3vs I & I & 0.02327 & 0.36156 & 0.0041 & 0.9487 & 1.024 & 0.504 & 2.079 \\
\hline Tsize & I & 0.53014 & 0.19935 & 7.0723 & 0.0078 & 1.699 & 1.15 & 2.511 \\
\hline node & I & 0.15863 & 0.19203 & 0.6824 & 0.4087 & 1.172 & 0.804 & 1.707 \\
\hline Treatment & I & -0.63284 & 0.29747 & 4.526 & 0.0334 & 0.531 & 0.296 & 0.951 \\
\hline VEGF_3group & I & 0.47637 & 0.1597 & 8.8972 & 0.0029 & 1.61 & 1.177 & 2.202 \\
\hline $\mathrm{GHI}$ & I & 0.24924 & 0.22057 & 1.2769 & 0.2585 & 1.283 & 0.833 & 1.977 \\
\hline Gene70 & I & 0.6283 & 0.33298 & 3.5605 & 0.0592 & 1.874 & 0.976 & 3.6 \\
\hline Wound_Response & I & 0.8087 & 0.35969 & 5.0549 & 0.0246 & 2.245 & 1.109 & 4.543 \\
\hline LumA_LumB & I & 0.74421 & 0.36168 & 4.2339 & 0.0396 & 2.105 & 1.036 & 4.276 \\
\hline LumA_Basal & I & -0.68615 & 0.48782 & 1.9785 & 0.1596 & 0.504 & 0.194 & 1.31 \\
\hline $\begin{array}{l}\text { LumA_Her2- } \\
\text { enrich }\end{array}$ & 1 & -0.16349 & 0.45232 & 0.1306 & 0.7178 & 0.849 & 0.35 & 2.061 \\
\hline LumA_Normal & I & 0.51006 & 0.37635 & 1.8368 & 0.1753 & 1.665 & 0.796 & 3.482 \\
\hline ER-regulated & 1 & 0.02629 & 0.32219 & 0.0067 & 0.935 & 1.027 & 0.546 & 1.93 \\
\hline TP53-associated & I & -0.0764 & 0.31658 & 0.0582 & 0.8093 & 0.926 & 0.498 & 1.723 \\
\hline
\end{tabular}


Table 3: Cox proportional hazards models for relapse-free survival using the NKI 295 patient test data set - backwards selected model from Table 2B showing the final parameters

\begin{tabular}{|c|c|c|c|c|c|c|c|c|}
\hline \multirow{2}{*}{$\begin{array}{l}\text { Variable } \\
\text { Age }\end{array}$} & \multirow{2}{*}{$\begin{array}{l}\text { DF } \\
1\end{array}$} & \multirow{2}{*}{$\begin{array}{l}\text { Estimate } \\
-0.052790 .0\end{array}$} & \multirow{2}{*}{$\begin{array}{l}\text { Standard Error } \\
|75|\end{array}$} & \multirow{2}{*}{$\begin{array}{l}\text { Chi-Square } \\
9.0867\end{array}$} & \multirow{2}{*}{$\begin{array}{l}\text { Pr }>\text { ChiSq } \\
0.0026\end{array}$} & \multirow{2}{*}{$\begin{array}{l}\text { Hazard Ratio } \\
0.949 \\
\end{array}$} & \multicolumn{2}{|c|}{$\begin{array}{l}\text { 95\% Hazard Ratio Confidence } \\
\text { Limits }\end{array}$} \\
\hline & & & & & & & 0.917 & 0.982 \\
\hline Tsize & I & 0.50134 & 0.19171 & 6.8387 & 0.0089 & 1.651 & 1.134 & 2.404 \\
\hline Treatment & I & -0.489020 .1 & |973| & 6.1425 & 0.0132 & 0.613 & 0.417 & 0.903 \\
\hline VEGF_3group & $\mathbf{I}$ & 0.46592 & 0.14522 & 10.2939 & 0.0013 & 1.593 & 1.199 & 2.118 \\
\hline Gene70 & I & 0.80232 & 0.27062 & 8.7898 & 0.003 & 2.231 & 1.312 & 3.791 \\
\hline Wound_Response & I & 0.89085 & 0.33694 & 6.9903 & 0.0082 & 2.437 & 1.259 & 4.717 \\
\hline LumA_LumB & I & 0.8682 & 0.23035 & 14.2059 & 0.0002 & 2.383 & 1.517 & 3.742 \\
\hline LumA_Normal & I & 0.67587 & 0.29743 & 5.1638 & 0.0231 & 1.966 & 1.097 & 3.521 \\
\hline
\end{tabular}

arrays for each predictor and followed the classification scheme described by the authors. For the bone metastasis signature [14], we created an average value for each patient using the 43 genes that were highly expressed in the cell line derivatives that metastasized to the bone; we performed a similar analysis for the lung metastasis signature [15].

Lastly, for the 11-gene stem cell signature [34], we created an average value across all 11 genes. We also created a 'glycolysis-profile' by starting with the nine glycolysis genes/ probes present on the array, then filtering for probes that showed > 30 intensity units in both channels, and then selecting for $70 \%$ good data across all samples; next we selected the subset of glycolysis gene probes that passed filtering and showed a Pearson correlation of greater than 0.4 , which resulted in the selection of six out of nine glycolysis genes (GPI, PKM2, PFKP, PGK1, GAPD, ENO1), which were then used to create an average profile for each patient.

We examined correlations between profiles using multiple methods (Additional file 1): for quantized profile testing, Chi-squared analysis and Fischer's exact test were used. For continuous variable testing, ANOVA analyses were performed. Finally, we also performed a calculation of the Cramer's V statistic for the evaluation of the strength of association between two quantized variables (see Oh et al [19]).

\section{Survival analyses}

Univariate Kaplan-Meier analysis was performed with a log-rank test using WinSTAT for excel. Multivariate analysis of the NKI295 test set using Cox proportional hazards modeling was conducted in SAS version 9.1; a Cox hazard model was tested that included estrogen receptor status (coded as positive vs. negative), tumor size (coded as $\leq 2$ $\mathrm{cm}$ vs. $>2 \mathrm{~cm}$ ), lymph node status (codes as $0,1-3,>3$ positive nodes or $M=1$ ), age (continuous variable, formatted in decades), grade (coded as grade 1 vs. 2 , and grade 1 vs. 3 ), and treatment (coded as yes if treatment with chemo and/or hormonal therapy, no if no adjuvant therapy was given), and the VEGF profile of low, intermediate or high as a single categorical variable. Another Cox model was also tested that included all the clinical variables, the VEGF profile, and other expression predictors $[11,13,18,19,28,35]$.

\section{In situ hybridization and immunohistochemistry}

In situ hybridization (ISH) on tissue microarrays containing 250 different human breast tumors (not related to the 146 patients used for microarray analysis) was performed as previously described [36]. Briefly, digoxigenin (DIG)labeled sense and anti-sense RNA probes are generated by

Table 4: Cox proportional hazards models for relapse-free survival using the NKI 295 patient test data set - model containing the clinical variables and the VEGF-profile as a continuous variable

\begin{tabular}{|c|c|c|c|c|c|c|c|c|}
\hline \multirow{2}{*}{$\begin{array}{l}\text { Variable } \\
\text { Age }\end{array}$} & \multirow{2}{*}{$\begin{array}{l}\text { DF } \\
1\end{array}$} & \multirow{2}{*}{$\begin{array}{l}\text { Estimate } \\
-0.0589\end{array}$} & \multirow{2}{*}{$\begin{array}{l}\text { Standard Error } \\
0.01639\end{array}$} & \multirow{2}{*}{$\begin{array}{l}\text { Chi-Square } \\
12.906\end{array}$} & \multirow{2}{*}{$\begin{array}{l}\text { Pr }>\text { ChiSq } \\
0.0003\end{array}$} & \multirow{2}{*}{$\begin{array}{l}\text { Hazard Ratio } \\
0.943\end{array}$} & \multicolumn{2}{|c|}{$\begin{array}{l}\text { 95\% Hazard Ratio Confidence } \\
\text { Limits }\end{array}$} \\
\hline & & & & & & & 0.913 & 0.974 \\
\hline ER & 1 & 0.00607 & 0.25196 & 0.0006 & 0.9808 & 1.006 & 0.614 & 1.649 \\
\hline Grade2vsI & 1 & 0.82592 & 0.31135 & 7.0367 & 0.008 & 2.284 & 1.241 & 4.204 \\
\hline Grade3vs I & 1 & 0.78226 & 0.32128 & 5.9284 & 0.0149 & 2.186 & 1.165 & 4.104 \\
\hline Tsize & I & 0.31513 & 0.19566 & 2.5941 & 0.1073 & 1.37 & 0.934 & 2.011 \\
\hline node & 1 & 0.3314 & 0.17655 & 3.5233 & 0.0605 & 1.393 & 0.985 & 1.969 \\
\hline Treatment & 1 & -0.61996 & 0.27417 & 5.1133 & 0.0237 & 0.538 & 0.314 & 0.921 \\
\hline $\begin{array}{l}\text { VEGF_Continu } \\
\text { ous }\end{array}$ & I & 0.43301 & 0.12298 & 12.3972 & 0.0004 & 1.542 & 1.212 & 1.962 \\
\hline
\end{tabular}


PCR amplification of approximately 450 bp products with the T7 promoter incorporated into the primers; the primer sequences used for amplification were VEGF (Forwardtctccctgatcggtgacagt, Reverse-tcgaaaaactgcactagagacaa), ANGPTL4 (Forward: gggaatcttctggaagacctg, Reversetacacacaacagcaccagca) and ADM (Forward-gtgtttgccaggcttaagga, Reverse-tcggtgtttccttcttccac). In vitro transcription was performed with a DIG RNA-labeling kit and T7 polymerase according to the manufacturer's protocol (Roche Diagnostics, Indianapolis, IN). Immunohistochemistry (IHC) was performed for HIF $1 \alpha$ using Mouse Anti-Human HIF1 $\alpha$ (BD Biosciences \#610958) according to the protocol from Vleugel et al [37]; the tumors were scored for perinecrotic and diffuse staining as described in Vleugel et al.

\section{Results}

\section{Expression patterns associated with metastases}

To identify gene expression patterns associated with breast cancer metastases, we performed 195 microarrays repre-
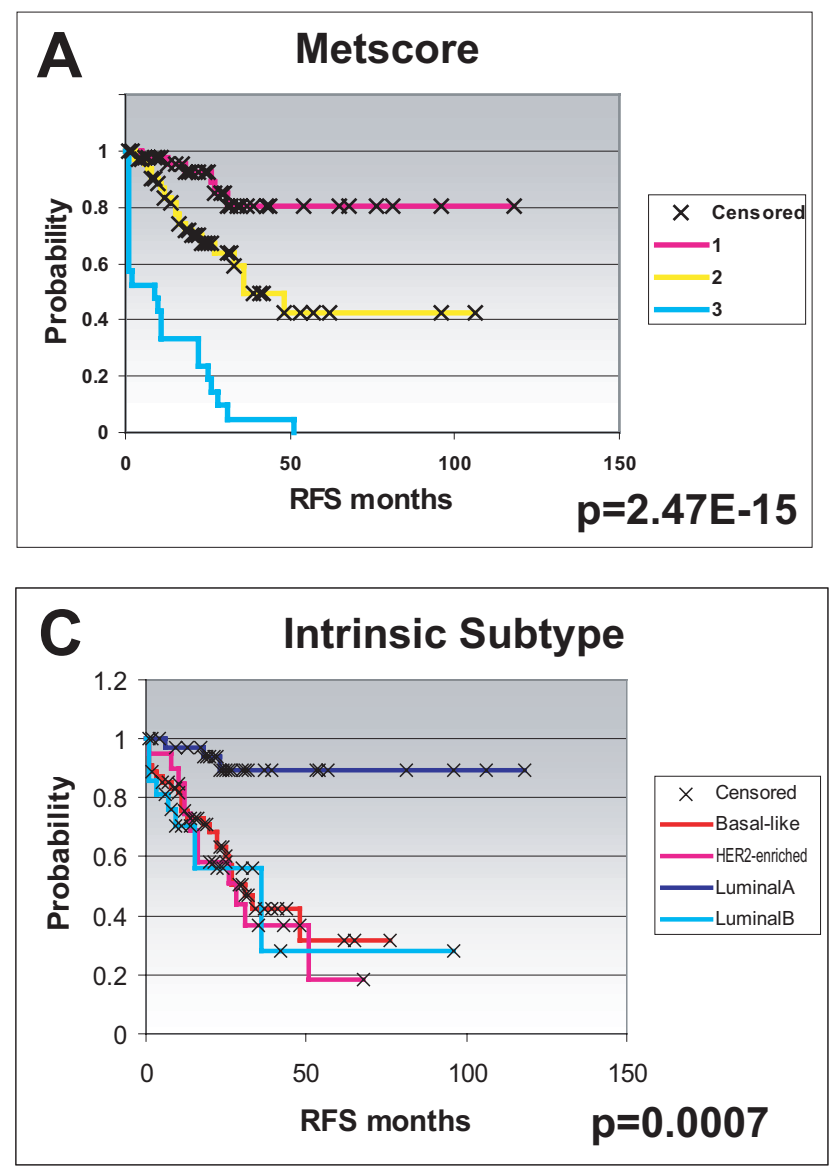

senting 134 primary tumors, nine regional metastases and 18 distant metastasis specimens (146 different patients and 10 normal breast tissues). Each patient was classified according to a MetScore, which is roughly analogous to stage except that tumor size was not considered (see Methods). As expected, this scoring system was highly predictive of patient outcomes (Figure 1A and 1B). Using the MetScore classifications, we performed CV analyses to determine if any MetScore group might be distinct relative to the others. Low accuracy rates (56\% to $65 \%$ ) for the prediction of MetScore 1 vs. MetScore 2 specimens were observed; however, when MetScore 1 vs. MetScore 3 (80\% to $85 \%$ ) or MetScore 2 vs. MetScore 3 samples ( $81 \%$ to $83 \%$ ) were compared, high accuracy rates were obtained, which suggests that MetScore 3 was the most distinct group.

Next, we performed a multi-class significance analysis of microarray [38] analysis using a single sample from each of the 146 patients and the MetScore 1-2-3 grouping and
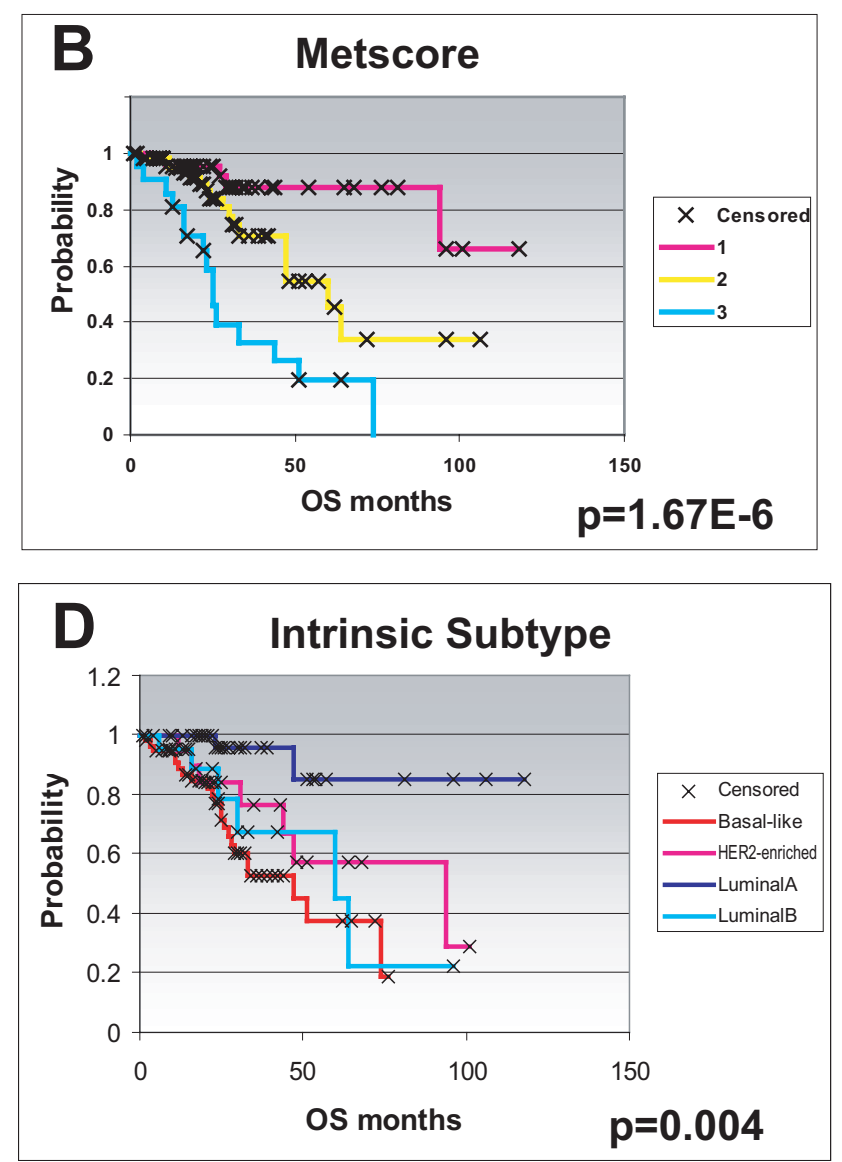

\section{Figure I}

Kaplan-Meier survival plots. Kaplan-Meier survival plots according to MetScore status (A and B) and according to intrinsic subtype (C and $\mathbf{D}$ ) across the 146 patient UNC training data set. 
obtained a 1195 genes at a $5 \%$ false discovery rate. This gene set was then used in a one-way average linkage hierarchical clustering analysis (Figure 2 and Additional file 2) where the samples were first ordered according to MetScore, and then according to their correlation to the average profile (that is, centroid) of the MetScore 3 class. This analysis demonstrates that some MetScore 1 and 2 samples actually have a MetScore 3 profile; a similar result has been shown before by Ramaswamy et al [9].

The gene expression patterns from this SAM analysis were complex and there were few, if any, that directly correlated with a simple progression from MetScore 1 to 2 to 3 . Included within this gene set were many clusters and/or gene sets that have been identified previously, including a
luminal/ER+ pattern $[11,39,40]$ and a proliferation signature $[41,42]$, both of which are integral parts of a gene expression assay that predicts the likelihood of recurrence in ER+ and patients treated with tamoxifen [13]. In addition, many other biologically important gene sets were identified, including an 'immediate early' gene cluster containing $c$-FOS and JUNB (Figure 2A) [43], a set of fibroblast genes containing PLAU, THSB2 and multiple collagen genes (Figure 2B), a set of immune cell genes (Figure 2D), and a gene set containing CXCL12 (Figure 2C); CXCL12 was the top-ranked gene from this SAM analysis and was recently identified as a chemokine whose high expression promotes tumor cell proliferation, migration and invasion [17]. Analysis of these individual clusters by EASE [44], with both EASE score and Bonferroni <

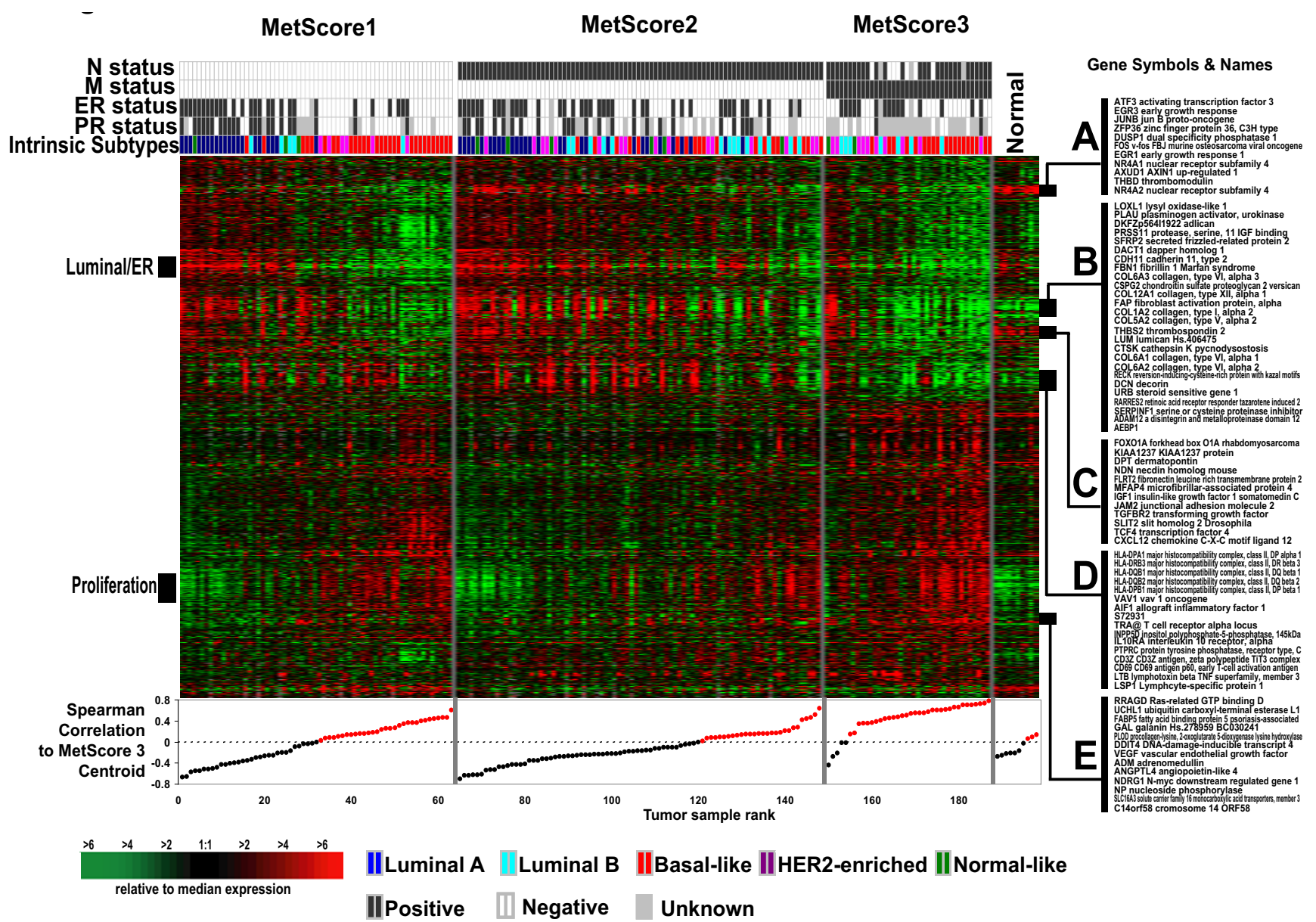

Figure 2

One-way average linkage hierarchical cluster analysis. One-way average linkage hierarchical cluster analysis of the gene set associated with MetScore status. One hundred and ninety-five microarrays, representing I46 tumors and I0 normal breast samples were analyzed using the II95 gene MetScore gene set. Overview of the complete cluster diagram (the full cluster diagram can be found as Additional file 2). The tumors were ordered according to their MetScore, and then according to their increasing correlation to the Metscore 3 centroid within each group. Clinical regional node status, distant metastasis status, ER, $\mathrm{PR}$, and intrinsic subtype are shown. A) FOS-JUN gene expression cluster, B) fibroblast/mesenchymal cell cluster, C) CXCLI 2 gene expression cluster, D), immune-cell/HLA cluster, E) VEGF profile. 
0.05 used as the cut off, identified many significant gene ontology categories that included 'transcription regulation' and 'DNA/nucleic acid binding' for the FOS-JUN cluster, while the fibroblast cluster was over-represented for 'extracellular matrix', 'cell adhesion and communication', 'organogenesis', 'development', and 'regulation of protease activity'. The CXCL12 cluster was over-represented for 'cell adhesion', 'cell migration' and 'extracellular matrix'. Lastly, a small 13-gene cluster containing VEGF, Adrenomedulin (ADM) and Angiopoietin-like 4 (ANGPTL4) was identified as the 'VEGF-profile' (Figure $2 \mathrm{E})$, which is discussed below in greater detail.

Our previous work identified five 'intrinsic' subtypes of breast cancer that are of prognostic and predictive value $[18,41,45]$. Subtype classification of the tumors using the centroid predictor from Hu et al [18] showed significant outcome predictions (Figure 1C and 1D). A Chi-squared test $(p=0.0006)$ showed that intrinsic subtype was significantly correlated with MetScore, with the Basal-like and HER2-enriched groups being the most frequent in MetScore 3 and with no Luminal A samples being in the MetScore 3 group. Correlations between tumor subtype and stage have been described $[46,47]$, and were recapitulated here.

\section{Analysis of the VEGF profile}

A small cluster of genes containing VEGF was identified (Figure 2E) that showed high expression in MetScore 3 tumors. This gene cluster contained several secreted proteins that have been implicated in endothelial cell (VEGF and ANGPTL4), lymphatic cell (ADM) and smooth muscle cell (GAL) dynamics. As a step in evaluating this profile, we performed ISH to determine what cell type was producing VEGF, ANGPTL4 and ADM. In the vast majority of cases that showed strong ISH positivity (which totaled approximately $10 \%$ of the 250 tumors tested), it was the tumor cells themselves that produced the mRNA for these three genes, and typically all three were produced (Figure 3). In a few cases, both tumor and fibroblasts showed ISH positivity, but this was rare.

As a second step in the evaluation of the VEGF profile, we created an average expression ratio of the 13 genes for each patient and looked for correlations with outcome. By dividing the patients into low, intermediate and highexpression groups using relapse-free survival (RFS) and cutoffs determined by X-tile [27], we saw that the VEGF profile was prognostic of RFS (Figure 4A) and overall survival (data not shown) with the high expression portending a poor outcome. Rank order expression classifications (two or three groups) were also robust methods of predicting outcomes (Additional file 3). Applying the VEGF profile classification rules to an independent test set of 295 patients (that is, NKI295) $[10,28]$ also significantly
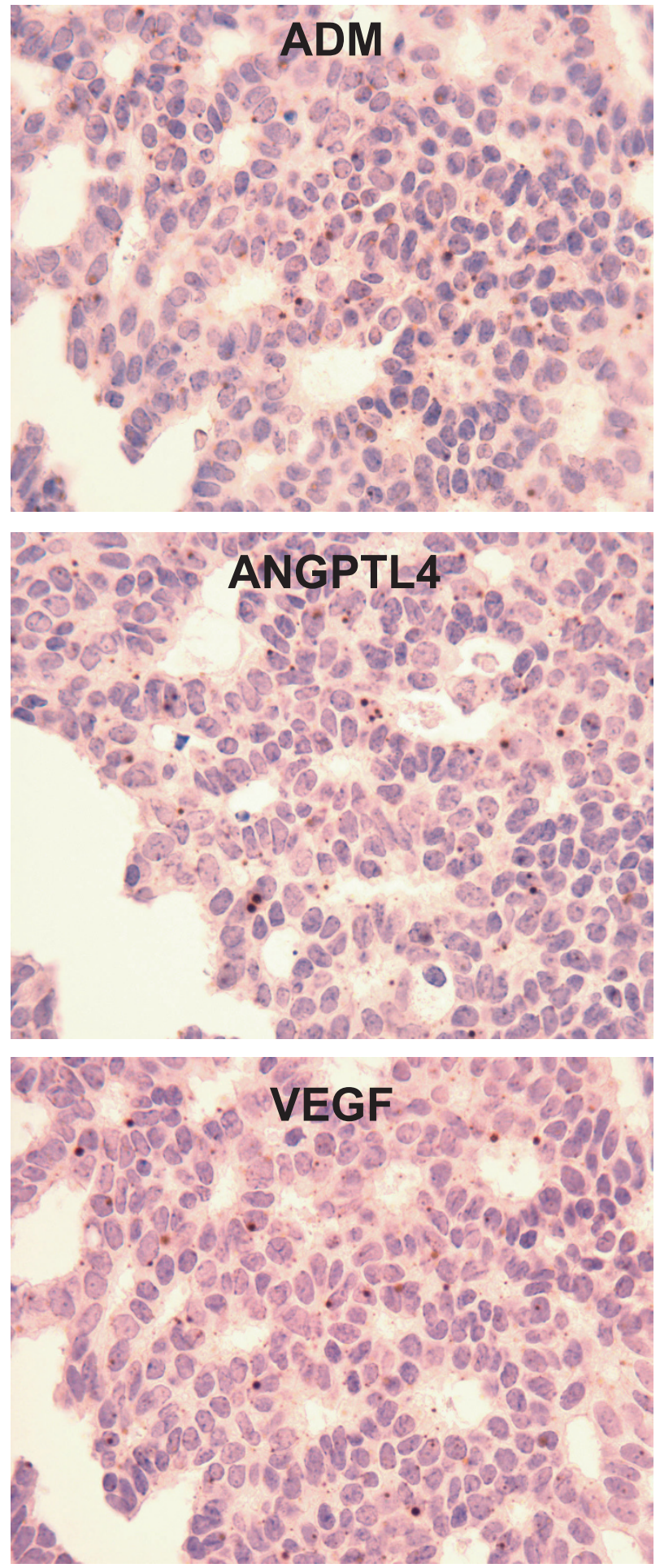

Figure 3

In situ hybridization. In Situ hybridization to localize gene transcripts using a representative tumor for $\mathbf{A}$ ) Adrenomedulin (ADM), B) Angiopoetin-like 4 (ANGPLT4), and C) Vascular Endothelial Growth Factor A (VEGF). Magnification 200x. 
UNC Training Dataset $(\mathrm{N}=136)$

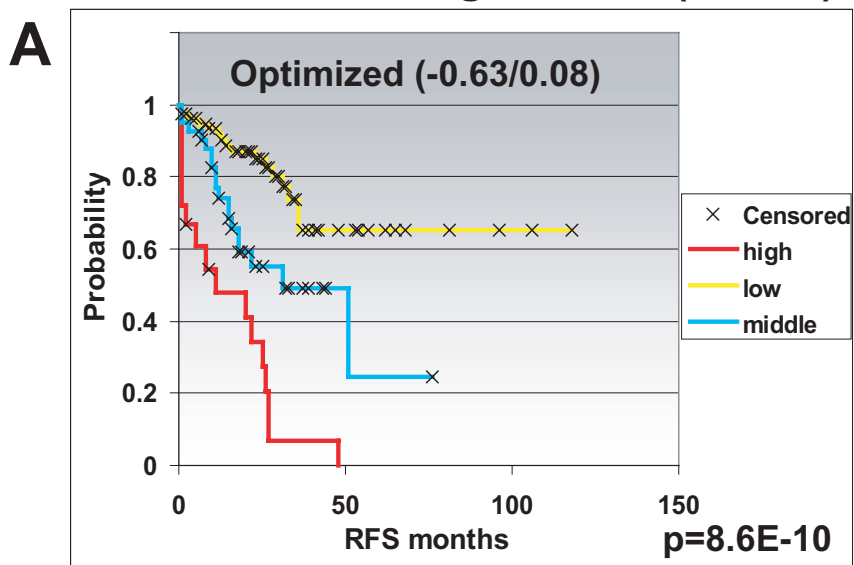

NKI Test Dataset $(\mathrm{N}=295)$

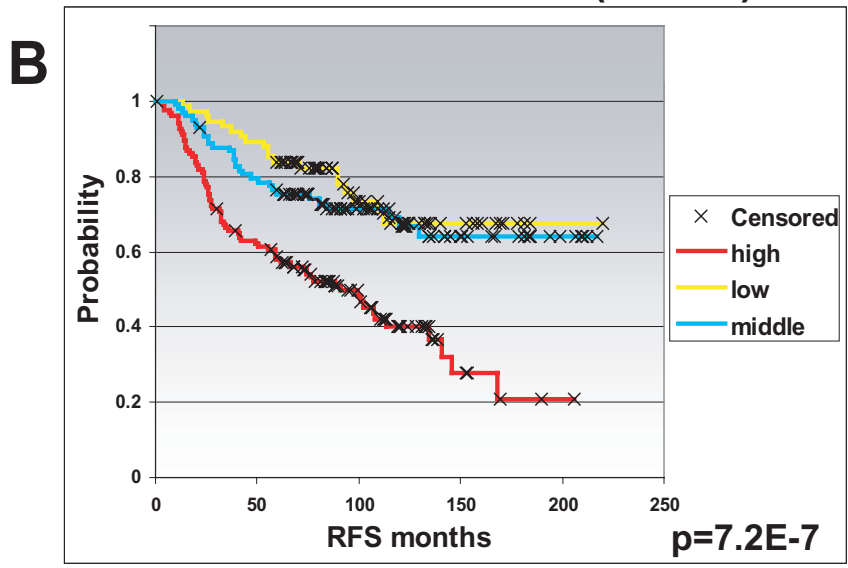

\section{Bhattacharjee et al Lung Cancer $(\mathrm{N}=111)$}

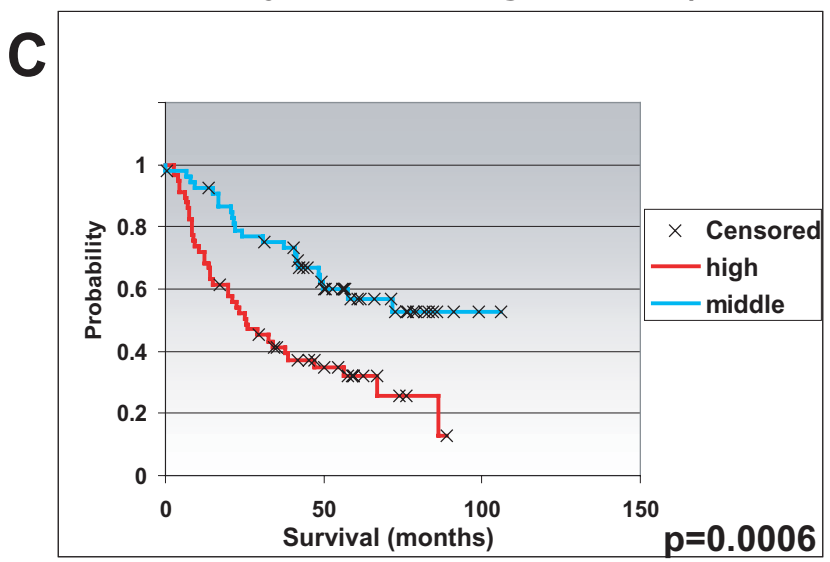

Nutt et al. Glioma ( $N=50)$

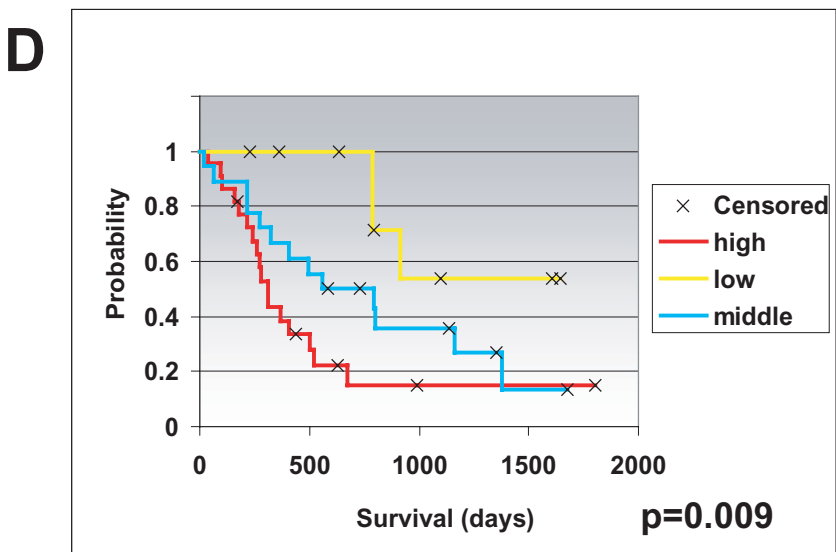

\section{Figure 4}

Univariate Kaplan-Meier survival plots. Univariate Kaplan-Meier survival plots of survival for patients stratified using the VEGF profile on the A) UNC training data set, B) NKI test data set, C) Bhattacharjee et al lung carcinoma data set [29], and D) Nutt et al glioblastoma data set [30]. Note: two genes ANGPTL4 and CI 4ORF58 were not found on Affymetrix platforms for $C$ and D.

predicted outcomes (Figure 4B), as did rank order classifications (Additional file 3). This classification rule was also of prognostic value on a set of lung carcinoma samples (Figure 4C and Additional file 3E and 3F), although there were too few 'low' samples to be included into the KaplanMeier plot analysis, and on a set of patients with glioblastoma (Figure 4D and Additional file 3G and $3 \mathrm{H}$ ); we noted that two genes (ANGPTL4 and C14ORF58) were not found on the Affymetrix platform for lung and glioblastoma test data sets. However, the Pearson correlation is 0.992 (UNC training dataset) and 0.986 (NKI295 test dataset) respectively between the average of the 13 genes and that of the 11 genes (omitting ANGPTL4 and C14ORF58). We repeated the survival analysis for the
UNC dataset and NKI test set again using the 11 genes and the results were very similar (data not shown).

A multivariate Cox proportional hazards analysis on the NKI295 test set using RFS was performed using clinical variables and the VEGF profile, and it was determined that the VEGF profile was a significant predictor of RFS (Table 1). In Fan et al [48], we evaluated the prognostic powers and concordance across multiple expression predictors including the intrinsic subtypes, the NKI 70 gene signature, a microarray-based version of the Genomic Health Inc. Recurrence Score, and the wound-response profile using this same NKI patient data set, and we have also identified other profiles of prognostic significance includ- 
ing an estrogen pathway [19] and p53 mutation profiles [35]; therefore, we performed a Cox proportional hazards analysis (Table 2) with backwards variable selection (Table 3) to evaluate a model that contained all of the aforementioned gene expression predictors and clinical variables. The final model contained both clinical parameters and multiple gene expression predictors including the VEGF profile (Table 3). Similar results were obtained when using time to distant metastasis formation, or overall survival (data not shown), or when treating the VEGF profile as a continuous variable (Table 4).

\section{Analysis of a glycolysis-profile and HIFI $\alpha$ expression}

A biological implication of the VEGF profile is that it is related to a tumor's response to hypoxic conditions, which historically has been referred to as the Warburg effect $[49,50]$. A central tenant of the Warburg effect is that a tumor's metabolism becomes more dependent upon glycolysis due to anaerobic conditions. To examine glycolysis using a genomic approach, we created a 'glycolysisprofile' using the six most highly correlated glycolytic enzyme probes (GPI, PKM2, PFKP, PGK1, GAPD, ENO1, Figure 5A); the VEGF profile and the six best glycolysis probes were highly correlated $(p<0.001$, Table 5$)$.

HIF1 $\alpha$ is a known regulator of VEGF expression, and therefore we determined that HIF1 $\alpha$ mRNA gene expression was correlated with the VEGF profile $(p=0.0004$; Table 5); in addition, 'perinecrotic' HIF1 $\alpha$ IHC staining as defined by Vleugel et al [37] was also assayed on a subset

Table 5: Correlation analysis of multiple gene expression profiles linked to metastasis biology or formation compared with each other

\begin{tabular}{lllll}
\hline Quantized Variables Testing & & & \\
\hline Primary Signature & Test Signature & Ch-aquare P-value & Cramer's V & Fisher Exact P-value \\
\hline VEGF profile & MetScore & 0.0002 & 0.272 & $4.80 \mathrm{E}-04$ \\
VEGF profile & NKI 70-gene profile & 0.0008 & 0.3126 & $3.60 \mathrm{E}-04$ \\
VEGF profile & Wound Response Profile & 0.0001 & 0.3524 & $3.78 \mathrm{E}-06$ \\
VEGF profile & Intrinsic Subtype & $<0.0001$ & 0.4223 & $4.29 \mathrm{E}-11$ \\
VEGF profile & hypoxia-signature & $<0.0001$ & 0.6394 & $1.10 \mathrm{E}-15$ \\
VEGF profile & hypoxia-metagene (50:50) & $<0.0001$ & 0.5722 & $8.29 \mathrm{E}-12$ \\
& & & & $7.09 \mathrm{E}-04$ \\
Intrinsic Subtype & MetScore & 0.0054 & 0.2578 & $1.40 \mathrm{E}-20$ \\
Intrinsic Subtype & Hypoxia signature & $<0.0001$ & 0.739 & $4.29 \mathrm{E}-11$ \\
Intrinsic Subtype & VEGF profile & $<0.0001$ & 0.4223 & $5.94 \mathrm{E}-06$ \\
Intrinsic Subtype & NKI 70-gene profile & $<0.0001$ & 0.7449 & $1.56 \mathrm{E}-16$ \\
Intrinsic Subtype & Wound Response Profile & $<0.0001$ & 0.5181 & $4.91 \mathrm{E}-09$ \\
Intrinsic Subtype & Hypoxia metagene (50:50) & $<0.0001$ &
\end{tabular}

Continuous Variables Testing

\begin{tabular}{lll}
\hline Primary Signature & Test Signature & ANOVA P-value \\
\hline VEGF profile & BoneMeta 43 Up genes Average & $<0.000$ I \\
VEGF profile & Breast2Lung-Average & $<0.000$ I \\
VEGF profile & Snail & $<0.000$ I \\
VEGF profile & TwistI & 0.3 \\
VEGF profile & II stem cell signature-Average & 0.0074 \\
VEGF profile & 6-Best-Glycolysis-Probes & $<0.0001$ \\
VEGF profile & Fibroblast-line-Avg & 0.7 \\
VEGF profile & HIFIA & 0.0004 \\
VEGF profile & hypoxia-metagene (50:50) & $<0.0001$ \\
& & \\
Intrinsic Subtype & BoneMeta 43 Up genes Average & 0.054 \\
Intrinsic Subtype & Breast2Lung-Average & 0.036 \\
Intrinsic Subtype & Snail & 0.0002 \\
Intrinsic Subtype & Twist I & 0.2 \\
Intrinsic Subtype & II stem cell signature-Average & $<0.0001$ \\
Intrinsic Subtype & 6-Best-Glycolysis-Probes & $<0.0001$ \\
Intrinsic Subtype & Fibroblast-line-Avg & 0.012 \\
Intrinsic Subtype & HIFIA & 0.0033 \\
Intrinsic Subtype & hypoxia-metagene (50:50) & $<0.0001$ \\
\hline
\end{tabular}



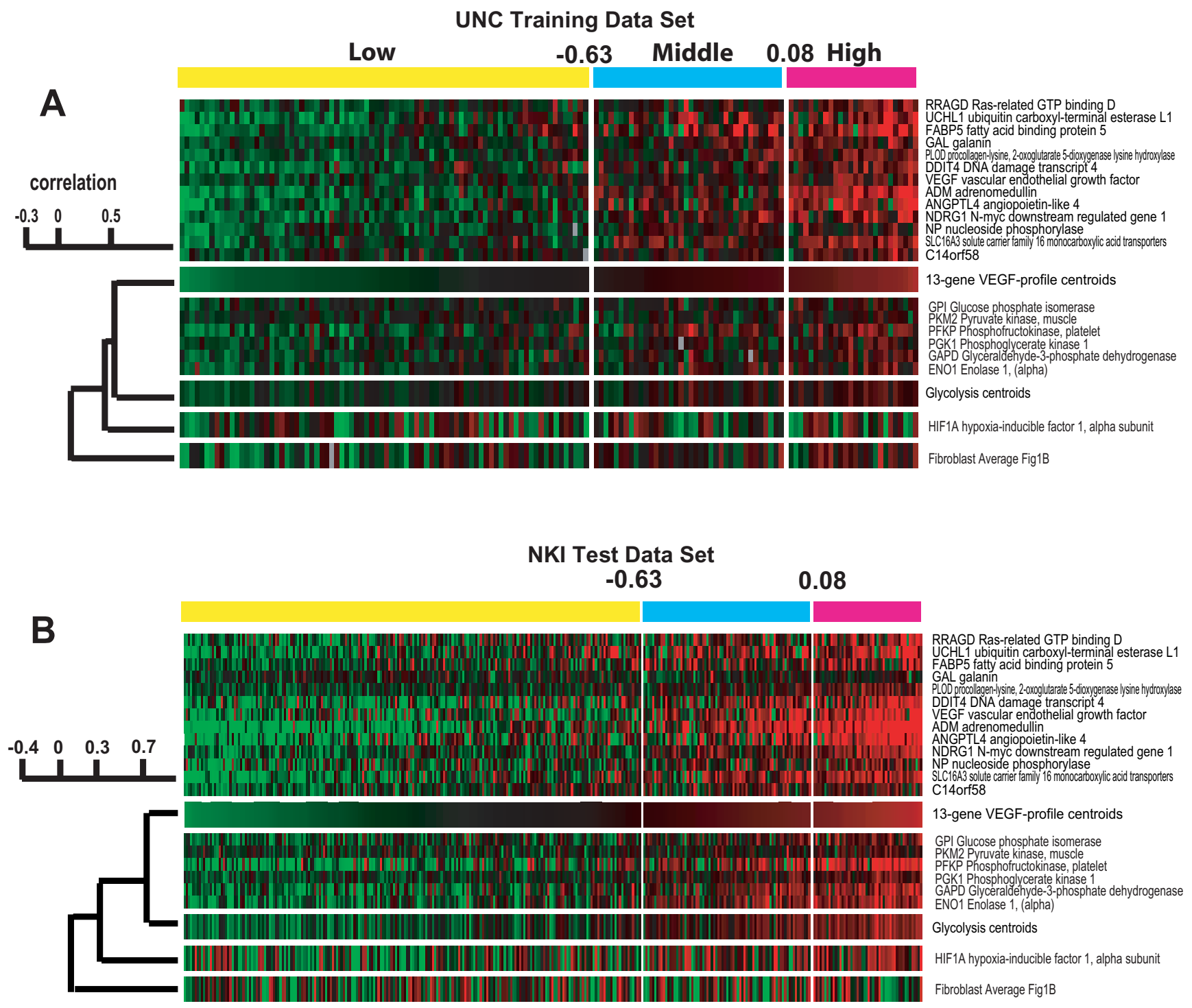

Figure 5

VEGF profile, glycolysis and HIF I $\alpha$ gene expression analyses. A) Gene expression for the VEGF profile (plus average values), for the six glycolysis genes and glycolysis centroid, HIFI $\alpha$ and fibroblast centroids are shown across the 146 patient UNC training data set with the tumors ordered according to their VEGF profile average values. B) Similar analysis as presented in A except the data set is the NKI patient test set.

of 66 of these tumors and was correlated with expression of the VEGF profile (ANOVA $p$-value $=0.018$, data not shown), while a 'diffuse' HIF1 $\alpha$ IHC profile was not. Next, the promoter region of each of the genes in the VEGF profile was examined using the program rVISTA [51] and showed that DDIT4, VEGF, NDRG1, SLC16A3, PLOD, ADM, ANGPTL4 and C14ORF58 all had hypoxia response elements within 2000 bp upstream of their start codons; it is already known that many of these genes including VEGF [52], ADM [53], and DDIT4 [54] are HIF1 $\alpha$-regu- lated. Nearly identical genomic results were also obtained from the NKI295 test set (Figure 5B).

\section{Fibroblast signature}

A fibroblast/mesenchymal signature was another profile that changed with MetScore (Figure 2B), and thus to examine the potential fibroblast cell content present within each MetScore group we determined each patient's average expression value of the genes contained with the cluster presented in Figure 2B. This gene set contains fibrillin, fibroblast activation protein alpha, six collagen 
protein subunits and versican, which are genes and/or proteins that are typically produced by fibroblast and/or mesenchymal cells [55]. This analysis shows that the fibroblast profile is correlated with intrinsic subtype (Table 5, $p=0.012$ ) and that the MetScore 3 samples had the lowest average expression compared with the MetScore 1 and 2 samples (ANOVA $p$-value $=0.005$, data not shown). Pathological examination of H\&E sections of the distant metastasis samples also supports this conclusion and shows scant admixed mesenchymal cells in the distant metastasis samples versus their primaries that show abundant admixed mesenchymal cells (Figure 6).

\section{Correlations between multiple metastasis associated profiles}

We examined whether the intrinsic subtypes, the MetScore classification, and the VEGF signature correlated with any of the following expression profiles that have been associated with metastatic potential: a) the NKI 70gene predictor $[10,11], \mathrm{b})$ the 'wound-response' profile $[32]$, c) a cell line-derived hypoxia profile [33], d) an 11gene $\mathrm{BMI} / \mathrm{stem}$ cell signature [34], e) a bone metastasis signature [14], f) a lung metastasis signature [15], g) a hypoxia metagene [56], and h) the expression profile of three individual genes (HIF1 $\alpha$, Snail [3], and Twist [16]). These analyses identified a large amount of concordance across profiles (Table 5). For example, the breast tumor subtype was significantly correlated with the bone and lung profiles, Snail expression, and the 11-gene stem cell signature; in particular, the bone and lung profiles were associated with both ER-negative subtypes (Basal-like and HER2-enriched), and Snail expression and the 11-gene stem cell signature were the highest within the Basal-like subtype. Similar results were also observed when the VEGF profile was compared with the other profiles. Two 'hypoxia signatures' have been described and shown to be of prognostic value across a variety of tumor types including breast $[33,56]$; the large signature of Chi et al [38] showed a four-gene overlap with the VEGF profile (ADM, NDRG1, DDIT4 and ANGPLT4) while the 'hypoxia-metagene' of Winter et al [56] showed a three-gene overlap (VEGF, NDRG1 and ANGPLT4); as might be expected, all three of these profiles were correlated (Table 5, $p<$ 0.0001).

\section{Discussion}

We took a genomics approach to study metastasis biology and classified patients with breast cancer according to the presence and location of their metastases (that is, MetScore). The resulting analyses showed that the most distinct group with the most distinguishing features were the distant metastases; few differences were seen between primary tumors and regional metastases, as has been shown before [57]. When the set of genes that were correlated with MetScore was determined, many previously known
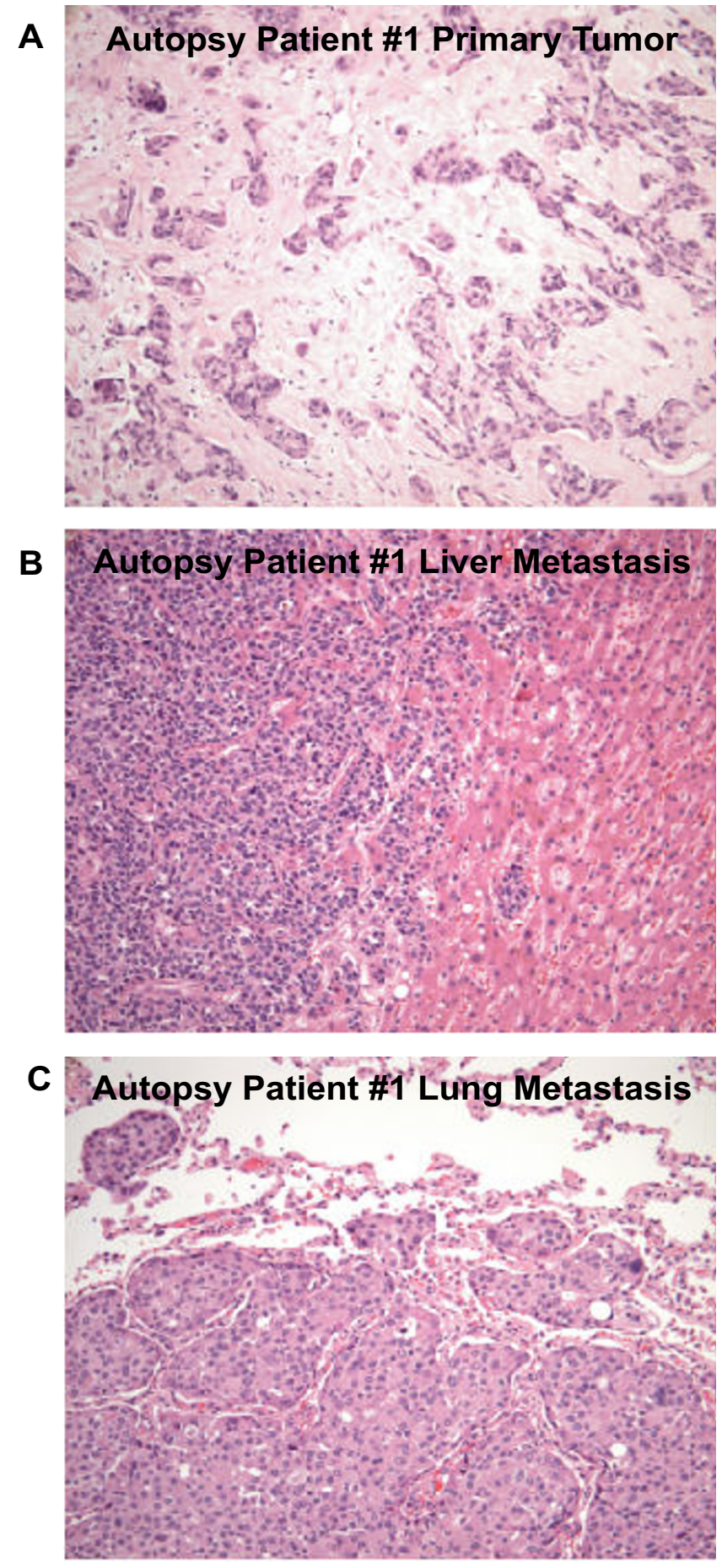

Figure 6

H\&E images of a primary breast tumor taken from a MetScore 3 patient. Showing a prominent admixed stromal component comprised of fibroblasts and myofibroblasts in the primary tumor. The fibroblast/myofibroblast component is markedly diminished in the distant metastatic sites (B and $\mathbf{C})$ as compared with the primary tumor (A). Magnification $200 \times$. 
gene sets were identified including proliferation [58], ER status $[11,39,40]$, and fibroblast and/or mesenchymal genes [55,59]. Notable distant metastasis features included the low expression of fibroblast genes (and a corresponding paucity of fibroblasts as defined by histological examination) and the high expression of the VEGF profile. The VEGF profile represents a in vivo defined gene expression program that includes a combination of cellintrinsic and cell-extrinsic factors. The cell-extrinsic factors have known roles as inducers of endothelial cell growth (VEGF and ANGPTL4), inducers of lymphatic vessel growth $(A D M)[60]$, and smooth muscle cell dynamics (GAL); thus, the expression of this gene set would appear to increase the likelihood of tumor survival by causing de novo vessel formation and providing a dual conduit for metastatic spread. The cell-intrinsic factors include the high expression of $S L C 16 A 3$, whose function is to efflux the lactic acid out of the cell that occurs during high glycolytic activity, and the expression of NDRG1, which is a known hypoxia-inducible gene $[61,62]$. In addition, the tumors that highly express the VEGF profile also highly express glycolytic enzymes. In total, our data suggests poor-outcome distant metastasis samples have the intrinsic ability to promote vessel formation, the intrinsic ability to live under anaerobic conditions, and have lost dependence upon fibroblasts.

Many genomic profiles for breast tumor metastasis biology have been identified, and we therefore compared them with each other and determined that significant correlations exist. In particular, all metastasis profiles tested correlated with 'intrinsic subtype'. For example, the Basallike subtype showed significant correlation with the 11gene stem cell profile, the lung and the bone metastasis profiles (consistent with these observations, one of the MetScore 3 Basal-like patients had distant metastases present in the bone, lung and liver). The Basal-like subtype also showed high expression of Snail, and Basal-like tumors have been shown to have other features of epithelial-mesenchymal transition [63] including vimentin expression [64].

\section{Conclusion}

The VEGF profile showed very significant prognostic value when using primary tumors, even when tested in models that contained many other expression predictors and clinical variables. We also believe it possible that the VEGF profile may have predictive value for angiogenesis inhibitors because it contains VEGF and ANGPTL4, which are inducers of angiogenesis. How, or if, the VEGF profile is correlated with response to angiogenesis inhibitors remains to be determined; however, our profile does suggests that effective anti-angiogenesis therapies for patients who express this profile may need to extend beyond VEGF to include the simultaneous targeting of ANGPTL4 and/or ADM.

\section{Abbreviations}

CV: Cross-Validation; DIG: Digoxigenin; DWD: Distant Weight Discrimination; ER: Estrogen Receptor; IHC: Immunohistochemistry; ISH: In-Situ Hybridization; MetScore: Metastasis Scoring System; NKI: Netherlands Cancer Institute; RFS: Relapse-Free Survival; SAM: Significance Analysis of Microarrays; UNC: University of North Carolina; VEGF: Vascular Endothelial Growth Factor.

\section{Competing interests}

$\mathrm{CMP}$ and $\mathrm{ZH}$ have filed a patent application for the use of the VEGF profile for breast cancer prognosis.

\section{Authors' contributions}

$\mathrm{ZH}, \mathrm{CF}, \mathrm{XH}, \mathrm{CL}$, DSO, SS, RW, FI and CMP made substantial contributions to the concepts, acquisition and analysis of the data. ZH, DSO, MGE, LAC, OIO, MVDR and CMP contributed significantly to the drafting of the manuscript and its intellectual content. All authors have read and approved the final manuscript.

\section{Additional material}

\section{Additional file 1}

Supplementary table. Summary of GEO submission of 202 microarrays used in this paper and clinical data of the patients in this study. Click here for file

[http://www.biomedcentral.com/content/supplementary/17417015-7-9-S1.xls]

\section{Additional file 2}

Figure S1. The complete cluster diagram of all 146 patients using the 1195 gene. MetScore-associated gene list.

Click here for file

[http://www.biomedcentral.com/content/supplementary/17417015-7-9-S2.pdf]

\section{Additional file 3}

Figure S2. Univariate Kaplan-Meier survival plots for patients stratified using the VEGF profile based upon rank order expression on the A-B) UNC training data set, C-D) NKI test data set, E-F) Bhattacharjee et al [29] lung carcinoma data set, and G-H) Nutt et al [30] glioblastoma data set.

Click here for file

[http://www.biomedcentral.com/content/supplementary/17417015-7-9-S3.pdf]

\section{Acknowledgements}

We thank J. Chuck Harrell for reviewing this manuscript. This work was supported by funds for CMP from the $\mathrm{NCl}$ Breast SPORE program to UNC-CH (P50-CA58223-09AI), by NCl (ROI-CA-I0I227-0I), by the Breast Cancer Research Foundation and by the $V$ Foundation for Cancer Research. LAC was supported in part by the National Institutes of Health 
(MOIRR00046), and OIO was supported by a Disparities Center Project Grant NIEHS P50 ESOI 2382.

\section{References}

I. Bernards R, Weinberg RA: A progression puzzle. Nature 2002, 4 I 8(6900):823.

2. Han B, Nakamura M, Mori I, Nakamura Y, Kakudo K: Urokinasetype plasminogen activator system and breast cancer (Review). Oncol Rep 2005, I 4(I): I05-II 2.

3. Moody SE, Perez D, Pan TC, Sarkisian CJ, Portocarrero CP, Sterner C], Notorfrancesco KL, Cardiff RD, Chodosh LA: The transcriptional repressor Snail promotes mammary tumor recurrence. Cancer Cell 2005, 8(3):197-209.

4. Wiseman BS, Werb Z: Stromal effects on mammary gland development and breast cancer. Science 2002, 296(5570): 1046-1049.

5. Leek RD: The prognostic role of angiogenesis in breast cancer. Anticancer Res 200I, 2I(6B):4325-433I.

6. Adriance MC, Inman JL, Petersen OW, Bissell MJ: Myoepithelial cells: good fences make good neighbors. Breast Cancer Res 2005, 7(5): 190-197.

7. Miller KD, Wang M, Gralow J, Dickler M, Cobleigh MA, Perez EA, Shenkier TN, Davidson NE: A randomized phase III trial of paclitaxel versus paclitaxel plus bevacizumab as first-line therapy for locally recurrent or metastatic breast cancer: a trial coordinated by the Eastern Cooperative Oncology Group (E2 I 00). San Antonio Breast Cancer Symposium: 2005; San Antonio, TX 2005.

8. Schneider BP, Sledge GW Jr: Drug insight: VEGF as a therapeutic target for breast cancer. Nat Clin Pract Oncol 2007, 4(3): $181-189$.

9. Ramaswamy S, Ross KN, Lander ES, Golub TR: A molecular signature of metastasis in primary solid tumors. Nat Genet 2003, 33(I):49-54

10. Vijver MJ van de, He YD, van't Veer LJ, Dai H, Hart AA, Voskuil DW, Schreiber G], Peterse JL, Roberts C, Marton MJ, Parrish M, Atsma D, Witteveen A, Glas A, Delahaye L, Velde $T$ van der, Bartelink $H$, Rodenhuis S, Rutgers ET, Friend SH, Bernards R: A gene-expression signature as a predictor of survival in breast cancer. $N$ Engl J Med 2002, 347(25): 1999-2009.

II. van 't Veer LJ, Dai $H$, Vijver $M J$ van de, He YD, Hart AA, Mao M, Peterse HL, Kooy K van der, Marton MJ, Witteveen AT, Schreiber GJ, Kerkhoven RM, Roberts C, Linsley PS, Bernards R, Friend SH: Gene expression profiling predicts clinical outcome of breast cancer. Nature 2002, 41 5(687 I):530-536.

12. Wang Y, Klijn JG, Zhang Y, Sieuwerts AM, Look MP, Yang F, Talantov D, Timmermans M, Meijer-van Gelder ME, Yu J, Jatkoe T, Berns EM, Atkins D, Foekens JA: Gene-expression profiles to predict distant metastasis of lymph-node-negative primary breast cancer. Lancet 2005, 365(9460):67I-679.

13. Paik S, Shak S, Tang G, Kim C, Baker J, Cronin M, Baehner FL, Walker MG, Watson D, Park T, Hiller W, Fisher ER, Wickerham DL, Bryant J, Wolmark N: A multigene assay to predict recurrence of tamoxifen-treated, node-negative breast cancer. N Engl] Med 2004, 35 I(27):28I7-2826.

14. Kang Y, Siegel PM, Shu W, Drobnjak M, Kakonen SM, Cordon-Cardo C, Guise TA, Massague J: A multigenic program mediating breast cancer metastasis to bone. Cancer Cell 2003, 3(6):537-549.

15. Minn AJ, Gupta GP, Siegel PM, Bos PD, Shu W, Giri DD, Viale A, Olshen $A B$, Gerald WL, Massague J: Genes that mediate breast cancer metastasis to lung. Nature 2005, 436(7050):5। 8-524.

16. Yang J, Mani SA, Donaher JL, Ramaswamy S, Itzykson RA, Come C, Savagner P, Gitelman I, Richardson A, Weinberg RA: Twist, a master regulator of morphogenesis, plays an essential role in tumor metastasis. Cell 2004, I I 7(7):927-939.

17. Allinen M, Beroukhim R, Cai L, Brennan C, Lahti-Domenici J, Huang H, Porter D, Hu M, Chin L, Richardson A, Schnitt S, Sellers WR, Polyak K: Molecular characterization of the tumor microenvironment in breast cancer. Cancer Cell 2004, 6(I): 17-32.

18. Hu Z, Fan C, Oh DS, Marron JS, He X, Qaqish BF, Livasy C, Carey LA, Reynolds E, Dressler L, Nobel A, Parker J, Ewend MG, Sawyer LR, Wu J, Liu Y, Nanda R, Tretiakova M, Ruiz Orrico A, Dreher D, Palazzo JP, Perreard L, Nelson E, Mone M, Hansen H, Mullins M, Quackenbush JF, Ellis MJ, Olopade OI, Bernard PS, Perou CM: The molecular portraits of breast tumors are conserved across microarray platforms. BMC Genomics 2006, 7(I):96.

19. Oh DS, Troester MA, Usary J, Hu Z, He X, Fan C, Wu J, Carey LA Perou CM: Estrogen-Regulated Genes Predict Survival in Hormone Receptor-Positive Breast Cancers. J Clin Oncol 2006, 24(I I): 1656-1664.

20. Weigelt B, Hu Z, He X, Livasy C, Carey LA, Ewend MG, Glas AM, Perou CM, Van't Veer LJ: Molecular portraits and 70-gene prognosis signature are preserved throughout the metastatic process of breast cancer. Cancer Res 2005, 65(20):9|55-9I58.

21. Hu Z, Troester M, Perou CM: High reproducibility using sodium hydroxide-stripped long oligonucleotide DNA microarrays. Biotechniques 2005, 38(I): 121-124.

22. Novoradovskaya N, Whitfield ML, Basehore LS, Novoradovsky A, Pesich R, Usary J, Karaca M, Wong WK, Aprelikova O, Fero M, Perou CM, Botstein D, Braman J: Universal Reference RNA as a standard for microarray experiments. BMC Genomics 2004, 5(I):20.

23. Eisen MB, Spellman PT, Brown PO, Botstein D: Cluster analysis and display of genome-wide expression patterns. Proc Natl Acad Sci USA 1998, 95(25): |4863-|4868.

24. Saldanha AJ: Java Treeview - extensible visualization of microarray data. Bioinformatics 2004, 20(I 7):3246-3248.

25. Tibshirani R, Hastie T, Narasimhan B, Chu G: Diagnosis of multiple cancer types by shrunken centroids of gene expression. Proc Natl Acad Sci USA 2002, 99( I 0):6567-6572.

26. Chung $\mathrm{CH}$, Parker JS, Karaca G, Wu J, Funkhouser WK, Moore D, Butterfoss D, Xiang D, Zanation A, Yin X, Shockley WW, Weissler MC, Dressler LG, Shores CG, Yarbrough WG, Perou CM: Molecular classification of head and neck squamous cell carcinomas using patterns of gene expression. Cancer Cell 2004, 5(5):489-500.

27. Camp RL, Dolled-Filhart M, Rimm DL: X-tile: a new bio-informatics tool for biomarker assessment and outcome-based cutpoint optimization. Clin Cancer Res 2004, I 0(2 I ):7252-7259.

28. Chang HY, Nuyten DS, Sneddon JB, Hastie T, Tibshirani R, Sørlie T, Dai H, He YD, van't Veer LJ, Bartelink H, Rijn M van de, Brown PO, Vijver MJ van de: Robustness, scalability, and integration of a wound-response gene expression signature in predicting breast cancer survival. Proc Natl Acad Sci USA 2005, I 02( I 0):3738-3743.

29. Bhattacharjee A, Richards WG, Staunton J, Li C, Monti S, Vasa P, Ladd C, Beheshti J, Bueno R, Gillette M, Loda M, Weber G, Mark EJ, Lander ES, Wong W, Johnson BE, Golub TR, Sugarbaker DJ, Meyerson M: Classification of human lung carcinomas by mRNA expression profiling reveals distinct adenocarcinoma subclasses. Proc Natl Acad Sci USA 200I, 98(24): I 3790- I 3795.

30. Nutt CL, Mani DR, Betensky RA, Tamayo P, Cairncross JG, Ladd C, Pohl U, Hartmann C, McLaughlin ME, Batchelor TT, Black PM, von Deimling A, Pomeroy SL, Golub TR, Louis DN: Gene expressionbased classification of malignant gliomas correlates better with survival than histological classification. Cancer Res 2003, 63(7): I602-I607

3I. Benito M, Parker J, Du Q, Wu J, Xiang D, Perou CM, Marron JS: Adjustment of systematic microarray data biases. Bioinformatics 2004, 20(I): 105-II4.

32. Chang HY, Sneddon JB, Alizadeh AA, Sood R, West RB, Montgomery $\mathrm{K}$, Chi JT, Rijn M van de, Botstein D, Brown PO: Gene expression signature of fibroblast serum response predicts human cancer progression: similarities between tumors and wounds. PLoS Biol 2004, 2(2):E7.

33. Chi JT, Wang Z, Nuyten DS, Rodriguez EH, Schaner ME, Salim A Wang Y, Kristensen GB, Helland A, Børresen-Dale AL, Giaccia A, Longaker MT, Hastie T, Yang GP, Vijver MJ van de, Brown PO: Gene Expression Programs in Response to Hypoxia: Cell Type Specificity and Prognostic Significance in Human Cancers. PLoS Med 2006, 3(3):e47.

34. Glinsky GV, Berezovska $O$, Glinskii $A B$ : Microarray analysis identifies a death-from-cancer signature predicting therapy failure in patients with multiple types of cancer. J Clin Invest 2005, I I 5(6): I503-|52|.

35. Troester MA, Herschkowitz JI, Oh DS, He X, Hoadley KA, Barbier CS, Perou CM: Gene expression patterns associated with p53 status in breast cancer. BMC Cancer 2006, 6:276.

36. West RB, Corless CL, Chen X, Rubin BP, Subramanian S, Montgomery K, Zhu S, Ball CA, Nielsen TO, Patel R, Goldblum JR, Brown $\mathrm{PO}$, Heinrich MC, Rijn M van de: The novel marker, DOGI, is 
expressed ubiquitously in gastrointestinal stromal tumors irrespective of KIT or PDGFRA mutation status. Am J Pathol 2004, I65(I): 107-II3.

37. Vleugel MM, Greijer AE, Shvarts A, Groep $P$ van der, van Berkel M, Aarbodem $Y$, van Tinteren $H$, Harris AL, van Diest PJ, Wall $E$ van der: Differential prognostic impact of hypoxia induced and diffuse HIF-I alpha expression in invasive breast cancer. I Clin Pathol 2005, 58(2): $172-177$.

38. Tusher VG, Tibshirani R, Chu G: Significance analysis of microarrays applied to the ionizing radiation response. Proc Natl Acad Sci USA 200I, 98(9):5।I6-5I2I.

39. Gruvberger S, Ringner M, Chen Y, Panavally S, Saal LH, Borg A, Ferno $M$, Peterson C, Meltzer PS: Estrogen receptor status in breast cancer is associated with remarkably distinct gene expression patterns. Cancer Res 200 I, 6 I (16):5979-5984.

40. Hoch RV, Thompson DA, Baker RJ, Weigel RJ: GATA-3 is expressed in association with estrogen receptor in breast cancer. Int J Cancer 1999, 84(2): I 22-1 28.

41. Perou CM, Sørlie T, Eisen MB, Rijn M van de, Jeffrey SS, Rees CA, Pollack JR, Ross DT, Johnsen H, Akslen LA, Fluge O, Pergamenschikov A, Williams C, Zhu SX, Lønning PE, Børresen-Dale AL, Brown PO, Botstein D: Molecular portraits of human breast tumours. Nature 2000, 406(6797):747-752.

42. Whitfield ML, Sherlock G, Saldanha AJ, Murray JI, Ball CA, Alexander KE, Matese JC, Perou CM, Hurt MM, Brown PO, Botstein D: Identification of genes periodically expressed in the human cell cycle and their expression in tumors. Mol Biol Cell 2002, I3(6): 1977-2000.

43. lyer VR, Eisen MB, Ross DT, Schuler G, Moore T, Lee JC, Trent JM, Staudt LM, Hudson J Jr, Boguski MS, Lashkari D, Shalon D, Botstein $\mathrm{D}$, Brown PO: The transcriptional program in the response of human fibroblasts to serum [see comments]. Science 1999, 283(5398):83-87

44. Hosack DA, Dennis G Jr, Sherman BT, Lane HC, Lempicki RA: Identifying biological themes within lists of genes with EASE. Genome Biol 2003, 4( I 0):R70.

45. Sorlie T, Tibshirani R, Parker J, Hastie T, Marron JS, Nobel A, Deng S, Johnsen H, Pesich R, Geisler S, Demeter J, Perou CM, Lønning PE, Brown PO, Børresen-Dale AL, Botstein D: Repeated observation of breast tumor subtypes in independent gene expression data sets. Proc Natl Acad Sci USA 2003, I 00(14):84I 8-8423.

46. Calza S, Hall P, Auer G, Bjöhle J, Klaar S, Kronenwett U, Liu ET, Miller L, Ploner A, Smeds J, Bergh J, Pawitan Y: Intrinsic molecular signature of breast cancer in a population-based cohort of 412 patients. Breast Cancer Res 2006, 8(4):R34.

47. Carey LA, Perou CM, Livasy CA, Dressler LG, Cowan D, Conway K, Karaca G, Troester MA, Tse CK, Edmiston S, Deming SL, Geradts ], Cheang MC, Nielsen TO, Moorman PG, Earp HS, Millikan RC: Race, breast cancer subtypes, and survival in the Carolina Breast Cancer Study. Jama 2006, 295(2I):2492-2502.

48. Fan C, Oh DS, Wessels L, Weigelt B, Nuyten DS, Nobel AB, van't Veer LJ, Perou CM: Concordance among gene-expressionbased predictors for breast cancer. N Engl J Med 2006, 355(6):560-569.

49. Warburg $\mathrm{O}:$ On respiratory impairment in cancer cells. Science 1956, I 24(3215):269-270.

50. Semenza GL, Artemov D, Bedi A, Bhujwalla Z, Chiles K, Feldser D, Laughner E, Ravi R, Simons J, Taghavi P, Zhong H: 'The metabolism of tumours': 70 years later. Novartis Found Symp 200I, 240:25I-260. discussion 260-254.

5I. Loots GG, Ovcharenko I, Pachter L, Dubchak I, Rubin EM: rVista for comparative sequence-based discovery of functional transcription factor binding sites. Genome Res 2002, I 2(5):832-839.

52. Fang J, Yan L, Shing Y, Moses MA: HIF- I alpha-mediated up-regulation of vascular endothelial growth factor, independent of basic fibroblast growth factor, is important in the switch to the angiogenic phenotype during early tumorigenesis. Cancer Res 200I, 61(15):5731-5735.

53. Frede S, Freitag P, Otto T, Heilmaier C, Fandrey J: The proinflammatory cytokine interleukin Ibeta and hypoxia cooperatively induce the expression of adrenomedullin in ovarian carcinoma cells through hypoxia inducible factor I activation. Cancer Res 2005, 65( I I):4690-4697.

54. Schwarzer R, Tondera D, Arnold W, Giese K, Klippel A, Kaufmann J: REDDI integrates hypoxia-mediated survival signaling downstream of phosphatidylinositol 3-kinase. Oncogene 2005 , 24(7): II38-1149.

55. Ross DT, Scherf U, Eisen MB, Perou CM, Rees C, Spellman P, lyer V, Jeffrey SS, Rijn M Van de, Waltham M, Pergamenschikov A, Lee JC, Lashkari D, Shalon D, Myers TG, Weinstein JN, Botstein D, Brown PO: Systematic variation in gene expression patterns in human cancer cell lines. Nat Genet 2000, 24(3):227-235.

56. Winter SC, Buffa FM, Silva P, Miller C, Valentine HR, Turley $H$, Shah KA, Cox G], Corbridge RJ, Homer J], Musgrove B, Slevin N, Sloan P, Price P, West CM, Harris AL: Relation of a hypoxia metagene derived from head and neck cancer to prognosis of multiple cancers. Cancer Res 2007, 67(7):344I-3449.

57. Weigelt B, Glas AM, Wessels LF, Witteveen AT, Peterse JL, van't Veer LJ: Gene expression profiles of primary breast tumors maintained in distant metastases. Proc Natl Acad Sci USA 2003, I00(26): I590I-I5905.

58. Whitfield ML, George LK, Grant GD, Perou CM: Common markers of proliferation. Nat Rev Cancer 2006, 6(2):99-106.

59. Ross DT, Perou CM: A comparison of gene expression signatures from breast tumors and breast tissue derived cell lines. Dis Markers 200I, 17(2):99-109.

60. Fritz-Six KL, Dunworth WP, Li M, Caron KM: Adrenomedullin signaling is necessary for murine lymphatic vascular development. J Clin Invest 2008, I I 8(1):40-50.

6I. Chen B, Nelson DM, Sadovsky Y: N-myc down-regulated gene I modulates the response of term human trophoblasts to hypoxic injury. J Biol Chem 2006, 28 I (5):2764-2772.

62. Okuda T, Kokame K, Miyata T: [Functional analyses of NDRG I, a stress-responsive gene]. Seikagaku 2005, 77(7):630-634.

63. Sarrio D, Rodriguez-Pinilla SM, Hardisson D, Cano A, Moreno-Bueno G, Palacios J: Epithelial-mesenchymal transition in breast cancer relates to the basal-like phenotype. Cancer Res 2008, 68(4):989-997.

64. Livasy CA, Karaca G, Nanda R, Tretiakova MS, Olopade OI, Moore $D T$, Perou CM: Phenotypic evaluation of the basal-like subtype of invasive breast carcinoma. Mod Pathol 2005.

\section{Pre-publication history}

The pre-publication history for this paper can be accessed here:

http://www.biomedcentral.com/1741-7015/7/9/prepub

Publish with Bio Med Central and every scientist can read your work free of charge

"BioMed Central will be the most significant development for disseminating the results of biomedical research in our lifetime. "

Sir Paul Nurse, Cancer Research UK

Your research papers will be:

- available free of charge to the entire biomedical community

- peer reviewed and published immediately upon acceptance

- cited in PubMed and archived on PubMed Central

- yours - you keep the copyright 